\title{
Chapter 3 \\ Reversing the Current: Small Scale Retention Programs in Polish Forests
}

\author{
Piotr Matczak, Viktória Takács and Marek Goździk
}

In this chapter, we present the small retention programs that have been undertaken in the Polish forests. The context of the programs is outlined with an emphasis on property rights, actors engaged, nature conservation and flood management aspects, and finally on the issues of up-scaling. After 1997 several small retention programs were introduced, reversing the earlier practice of drainage. The programs in the State Forests National Forest Holding consist in building a diverse range of small-scale, multi-functional retention facilities. The FRM aspect is more important in the mountain areas, while reducing forest fire risk is more important in the lowlands. Location of facilities was, in general, not problematic, as they were mostly built in the forests managed by the State Forests National Forest Holding. However, in particular locations, conflicts of interest or collisions between functions (wood production, nature conservation, etc.) occurred. Although the State Forests National Forest Holding manages the small retention programs, other stakeholders are engaged in planning small retentions also: the environmental protection administration, local governments, farmers, fishpond owners, etc. The program is based on a clear hierarchical managerial structure of the State Forests National Forest Holding, which makes the up-scaling aspect of the program straightforward.

\author{
P. Matczak $(\varangle)$ \\ Institute of Sociology, Adam Mickiewicz University in Poznań, Poznan, Poland \\ e-mail:matczak@amu.edu.pl \\ V. Takács \\ Institute of Zoology, Poznań University of Life Sciences, Poznan, Poland \\ e-mail: takacsviki@o2.pl \\ M. Goździk \\ Coordination Centre for Environmental Projects, The State Forests National Forest Holding, \\ Warsaw, Poland \\ e-mail: marek.gozdzik@ckps.pl \\ (C) The Author(s) 2019 \\ T. Hartmann et al. (eds.), Nature-Based Flood Risk Management on Private Land, \\ https://doi.org/10.1007/978-3-030-23842-1_3
}




\section{Introduction: Water Management in Poland in the Retention Context}

Water resources per capita in Poland are among the lowest in the EU. They are also unevenly spatially distributed: central Poland can be characterized as water deficient at a relatively lower level of precipitation than other regions (Mioduszewski and Pierzgalski 2009). Occasional droughts cause serious losses in agriculture.

At the same time, floods present the biggest natural hazard in Poland. The fluvial type of floods, caused by storms and sudden high precipitation, dominate in the country. It is estimated that in the post-war period (1946-2010), 600 floods have occurred, of which fifteen floods were classified as disastrous on at least a regional scale. Particularly, the floods in 1997 (on the Odra River) and in 2010 (on the Vistula and the Odra Rivers) caused serious material losses and dozens of casualties (Kundzewicz et al. 2012).

Agriculture intensification and homogenisation of landscape, construction of drainage systems as well as urban development have all resulted in sealing ground surfaces and have thus intensified flood risks significantly. The natural water retention capacity of catchments has decreased while the runoff paths have been streamlined causing a rapid runoff of precipitation and melting snow into rivers (Mioduszewski 2014).

Consequently, retention is badly needed in Polish water management in order to mitigate floods (Fournier et al. 2016). The very concept of retention as an approach in water resources and FRM stems from a conviction that occasional excess of water can be stored; this measure decreases the flood risk and secures water supply during water shortage. Retention is thus instrumental in FRM, agriculture production and also has other functions: water storage in case of wild fires, biodiversity protection, fish cultivation, positive influence on biodiversity and on landscape characteristics, which further results in more attractive recreational areas.

In this chapter, water retention in forested areas is presented-a new approach in flood management and water resources management that has been developed and applied for the last 20 years in Poland. The programs have relied on the concept of small retention. It is a term referring to various means and techniques aiming to limit the water runoff after heavy rains or snow melting. The main idea is to improve hydrographic conditions in a catchment by increasing the time and the track of water circulation (Mioduszewski 2014; Kowalczak 2002). Small retention facilities slow down water outflow from natural and artificial running waters, store waters in small reservoirs and terrain depressions and increase the retention of water in soils and aquifers (Kowalewski 2008).

"Small retention" is a term seldom used in other countries. In Poland, small retention is used in contrast to large multifunctional reservoirs, serving as drinking water intakes, power production facility, flood control etc. (Kowalewski 2008). This term has a meaning not far from the concepts of "natural retention" (Natural Water Retention Measures) (Koseoglu and Moran 2014) and "water harvesting”. Yet, the term of small retention has a wider scope as it denotes both technical measures and use of natural formations for retention purposes. 
In the following sections changes in the water management are presented, followed by the description of the small retention program in Polish forests. It is discussed in terms of implementation, measures, costs, function, property rights issues and up-scaling.

\section{The Small Retention Programs in Polish Forests}

The current efforts to retain water stem from the legacy of the communist period from 1945 to 1990 . In this time period, productivity was the main priority, resulting in significant development of drainage in agricultural areas (Mioduszewski 2014). The development of drainage systems contributed to the transformation of the water regime. The majority of small watercourses were regulated, and a number of dense networks of drainage ditches were constructed. As a result, in large areas the groundwater table has been excessively lowered (Mioduszewski 2014).

Polish forests were also drained, to increase timber productivity and grow forests on the wetlands. This approach was in accordance with the socialist economy features, including planned, industrialized economy development. As a result of this program, more than 850 thousand hectares of forested area were drained with further plans to continue. Drainage in forests led to the degradation of forest wetlands. The water table decreased, and many small wet areas and peatbogs disappeared (Miler 2015).

After 1990, with the collapse of the communist system, the drainage programme lost its importance. This was in line with the wider, radical change of the economic, political and administrative order in the country. From the beginning of the 1990s, new drainage facilities were built only occasionally, and the existing ones were not maintained and mostly became abandoned. New water and FRM policies were gradually built.

\section{The Small Retention Programs in Polish Forests}

Forests cover 9.2 million hectares, which is $29.5 \%$ of the territory of Poland; $82 \%$ of the forests are public. The State Forests (SF) National Forest Holding is a specific organisational structure established to manage the public forests, and it also plays a supervisory role for all forests. The dominant position of the public forestry sector-and especially the SF National Forest Holding, which is responsible for the management of most forests in the possession of the State Treasury-is the distinctive feature of the forest policy in Poland. After the collapse of the communist regime in 1990, the restitution of formerly nationalised forest estates has not taken place in Poland, unlike other Central European countries. It is due to the high degree of fragmentation of private forests, where the average area of a single forest holding is 1.3 ha (Zajac 2004). The resulting position of the SF National Forest Holding 
enables the agency to manage the majority of the Polish forests thus to implement a coherent National Forest Policy.

After 1990, the forest policy objectives have shifted. In a document regulating planning and forest management, the Forest Silva-culture Principles, sustainable elements of forestry were first mentioned. While timber production had previously been the priority, additional focus on sustainability principles and economically balanced the models gradually developed thereafter. The national forest policy concerning forests includes sustainable management and the maintenance of multi-functionality of forests. Small retention is a component of this shift, aligned with the general policy. In 1995, agreements between the Ministry of Agriculture and the Ministry of the Environment concerning cooperation about small retention were developed. Eventually, in 1997, the Director of the SF National Forest Holding initiated the small retention programme for the period of 1997-2007. The program was well received and it was decided to continue it. The second period was executed in the years 2008-2014, and the third period was planned for 2015-2022.

In the first period, 3340 retention objects were constructed: 727 small reservoirs were built, 4 lakes were dammed, and 1551 smaller ponds were created. Furthermore, over 800 objects were connected to basic and extended reclamation networks. Damming lakes and building reservoirs gave the highest result in retention capacity-over 50 million cubic metres both, while the rest of devices had far less capacity (Kowalewski 2008).

In 2006, the second period of the small retention program in the Polish forests was launched, consisting of two parts dedicated to the lowland and upland forests. Although the flood protection aspect was present in both parts, the emphasis was differently placed. In lowland forests, increasing retention capacities was intended mainly to prevent droughts and to fight wildfires. The program for the maintenance areas was designed to counteract the effects of rainwater runoff from the mountains, increase water retention capacity in watersheds, maintain torrents-related infrastructure in good condition, and reduce erosion (Pierzgalski et al. 2017).

\section{Implementation of the Small Retention Program in the Polish Forests}

The small retention methods can be roughly divided into two categories: natural and technical. The natural forms include any sort of land use change such as forestation areas alongside rivers, slope shaping, protection planting, revitalization and preservation of swamps, moors and marshes, soil structure improvement wetland restoration, re-meandering and others. The technical forms include building ponds, oxbow lakes, moats, clay pits, fire water reservoirs, damming on rivers and lakes, establishing the river polders, building buffer ponds in headwater catchments, and installing technical devices such as weirs, gates, and barrages. 
Implementation of small retention projects in forests has several advantages, such as the following: ensuring forest growth by raising water table; decreasing forest fire risk; increasing groundwater resources, runoff water purification; biodiversity conservation; providing waters intakes for irrigation, re-naturalization of wetland habitats and regulation of rivers, development of fishing resources (Mioduszewski 2014). Nevertheless, small retention can also have adverse effects related mainly to technical measures. In particular, building new reservoirs, besides restoring existing ones, can have negative effects on biodiversity; this matter will be discussed later.

Within the small retention programs, several measures were planned. Nevertheless, their small scale was the core of the programs. Small water storage facilities were planned at a maximum capacity of five million cubic metres, although in practice they have not exceeded one million cubic metres. Small retention ponds were intended mainly to improve water balances in the forest ecosystems (Pierzgalski et al. 2017).

The programs relied on several conditions when building the small retention facilities, including the following: (a) forests and buffer woods planting should reduce surface runoff; (b) the existing reclamation, irrigation, and water-lifting facilities should be maintained, in particularly those hampering water outflow; (c) local communities and regional boards of water management should be consulted when planning facilities; (d) facilities should be located in places facilitating the recharge of aquifers. These conditions were defined in the program document and in the good practice books prepared by the SF National Forest Holding units (CKPŚ 2008; Goździk et al. 2009; CKPŚ 2016).

About seven thousand measures and hydraulic devices were built within the programs in both up and lowland regions (see Table 3.1).

For the programming period 2014-2020, the upgrade and the new financial plan for the small retention program was designed. Similarly to the previous periods, the program is divided into mountain and lowland areas. However, climate change represents an additional rationale for action in this phase. The projects are called "Counteracting water erosion in mountain areas" and "The comprehensive project of adaptation of forests and forestry to climate change-small retention and counteracting water erosion in the lowland areas" (CKPŚ 2016).

The main goal for the next period is to strengthen the resilience to threats related to climate change in both low- and upland forest ecosystems. The activities are

Table 3.1 Small retention objects, retained water capacity and costs in upland and lowland forests within the programming period 2007-2013

\begin{tabular}{l|l|l|l}
\hline & No. of objects & $\begin{array}{l}\text { Retained water in million of } \\
\mathrm{m}^{3}\end{array}$ & Total cost \\
\hline Small retention on lowlands & 3644 & 42.8 & 44 million euro \\
\hline $\begin{array}{l}\text { Small retention on } \\
\text { highlands }\end{array}$ & 3553 & 1.5 & 43 million euro \\
\hline
\end{tabular}

SF National Forest Holding: http://www.ckps.lasy.gov.pl 
aimed at preventing or minimizing the negative effects of natural disasters such as the following: floods and inundations, droughts and wild forest fires via the development and maintaining the existing small retention systems, increasing the amount of stored water and counteracting excessive water erosion. Besides new retention objects, the program also hopes to reconstruct valuable natural ecosystems and biodiversity conservation and maintain the existing constructions. Monitoring is also an important element of the program, partially as the continuation of monitoring performed within the framework of the small retention program implemented within the previous periods.

\section{Measures Applied in the Small Retention Programs}

The small retention program has several preventative functions in case of floods, drought, wild fires, erosion, and other disasters, and for the conservation of biodiversity. Within the programs, several technical and non-technical measures were implemented, such as construction of close to nature ponds, lateral reservoirs, forestation revitalization of existing and dried pit areas (CKPŚ 2016).

Particular measures usually have functions that depend upon a specific situation in a location. Application of measures depends on local circumstances but is also driven by the building principles and the good practice books (CKPŚ 2008; Goździk et al. 2009; CKPŚ 2016) that were prepared within the program. For instance, building with the use of natural materials, minimizing the use of concrete, is advised as well as taking into account natural processes during implementation.

\section{Costs and Funding}

In the years 1997-2007 costs of the retention programs in Poland were covered mostly by public sources. Facilities were co-financed by budgets of provincial governments, the Provincial Funds for Environment Protection and Water Management, the National Fund for Environmental Protection and Water Management, local governments, the Fund for the Protection of Agricultural Lands (FPAL), and the Agency for Restructuring and Modernization of Agriculture (ARMA). About 25\% of costs were covered by private investments, mostly owners of private fish ponds, small hydroenergy production stations, fishing associations, mining companies, etc. Projects were financed on a competitive basis.

The largest sums spent came out of the budgets of provincial governments and the Provincial Funds for Environment Protection and Water Management. On average, the program's mean annual expenditure equalled EUR 12 million (Kowalewski 2008; Mioduszewski 2014).

Contrary to the first programming period, in the years 2007-2013, the program was financed mainly $(85 \%)$ by the EU Cohesion Fund, within the Operational Pro- 
gram Infrastructure and Environment, Action 3.1. In the end, the SF National Forest Holding financed approximately $30 \%$ of the program's costs. Funding was divided between lowlands and uplands. In both cases, it equalled about 44 million euro.

Funding for the programming period 2014-2020 is estimated to approximate EUR 55 million in lowland and EUR 49 million in upland areas.

Up to the year 2006 the most effective measure, for the whole country and among the various programmes, was lake damming, at a cost of $0.015-0.13$ euro per cubic metre. Lake retention requires relatively low inputs in terms of infrastructural investments. When the lake retention options were exhausted, other measures appeared less cost effective. They entailed higher costs per cubic metre of retained water. For instance, the cost of obtaining one cubic metre of retained water in the case of fishponds varied between EUR 0.5 and 1.4 per one cubic metre; the costs of the construction of artificial reservoirs appeared even higher and varied, from EUR 0.86 to 4.7 per one cubic metre (Kowalewski 2008; Tyszka 2009). On average, for the phase of 2007-2013, cost of retaining of one cubic metre equalled EUR 1.5 for the lowlands and EUR 10.4 for the mountain areas.

In terms of costs for various sizes of reservoirs, estimates suggest that small retention is about ten times cheaper than larger reservoirs. The cost of storage of one cubic metre of water in small retention facilities ranges from EUR 0.5 to 1.2, while large retention reservoirs range from EUR 3.6 to 9.5 per cubic metre (Liberacki et al. 2016; Miler 2015).

\section{Actors, Stakeholders and the Property Rights Aspect of the Programs in Poland}

Besides the units of the SF National Forest Holding, several administrative agencies were involved in retention programs in the country such as the water management bodies (The Regional Directorate of Water Management), flood risk managers (Institute of Meteorology and Water Management; Regional Drainage and Water Facilities Boards), the Provincial Funds for Environment Protection and Water Management, National Parks, Landscape Parks, Promotional Forest Complexes, municipalities, the county and the provincial administrations, and the special interests groups: naturalists; farmers, fish pond owners etc. Moreover, the small retention project had to be included in several long-term plans, in particular, the forest management plans, spatial development plans of municipalities, and management plans of the National Parks (Zając 2004).

Concerning the retention programs, cooperation on the local level with several environmental NGOs helped to plan and realise the programs in the Polish State Forests. Experts and NGOs helped in working out methods of locating and building small retention facilities (CKPŚ 2009; Jelonek et al. 2008; JASPERS 2009); NGOs were involved both during the planning and implementation phases. They provided advice in identification of new reservoirs locations and carrying out environmental procedures. 
The property rights issue appears relatively non-problematic in the programs. The majority of facilities were located in the forests managed by the SF National Forest Holding. From the perspective of the Holding, as the owner and the manager of forests, the small retention programs were not the core issue for the organisation. However, the programmes were in accordance with several of the Holding's objectives, such as nature conservation, forest management, etc. The decision to initiate the programs made it possible to use the vast forest areas for another purpose. Although it was seemingly not a deliberate decision from a FRM perspective (as the program aimed mostly at fire protection and drought management), the fact that facilities were built on the land of one owner was a fortunate condition. In cases where other stakeholders were involved, usually conflicts of interest occurred. Nevertheless, protection of the third parties' interests was mentioned in the good practice advice books prepared by the SF National Forest Holding units (CKPŚ 2008; Goździk et al. 2009; CKPŚ 2016).

\section{The Nature Conservation Aspect}

In practice, retention sites are often planned on already existing small wet areas, usually with a high natural value. The reason for this is that from the hydrological point of view the most suitable places for retention sites are existing small interforest wetlands. These sites are also appropriate from economic considerations as they usually hold a limited potential for production. They are often situated within Natura 2000 sites since $25 \%$ of lowland forests and over $90 \%$ of highland forests are part of Natura 2000 network. Therefore potential impacts on biodiversity are important issues.

In general, wetlands, swamps and small ponds in the forest are very important for biodiversity (Baldwin 2005). Wet sites in the forests directly increase both species and habitat diversity. This has a special importance in the case of forest monocultures where wet sites are one of the main sources of diversity within the monotonous landscape (Whitaker and Montevecchi 1997). Wet sites are habitats hosting a diverse wildlife. All taxonomic groups have representatives inhabiting inter-forest wet areas that are essential, especially for amphibians and migrating waterfowl (Baldwin et al. 2006; Di Mauro and Hunter 2002).

Additionally, wildlife benefits indirectly from the vicinity of wetlands and increasing forest moisture (Mioduszewski 2014) by augmenting forest growth and vegetation density. A survey of birds (other than waterfowl) showed that the vicinity of wet in forest increased both bird diversity and density in production forests. Apart from direct and indirect influences on biodiversity, wet sites in forests help to mitigate the negative impacts of forest management (Hanowski et al. 2006).

On the other hand, the creation of small retentions does not always comply with principles of biodiversity conservation. During the construction of retention projects, construction can destroy some natural ecosystems. Retention projects can also influence biodiversity indirectly. As this process always involves the creation of new 
habitats and changes in the water table, cleaning existing channels can lead to less predictable effects on biota (Wegner 1999; CKPŚ 2009): for example, destroying peat habitats by flood or changing the water regime can change water habitats for fish and water plants. These impacts are often difficult to detect and predict.

An additional potential risk is connected to changing the network of wet areas at a landscape scale. Newly filled ditches can allow for the migration of alien species such as the American mink (Neovison vison) along the newly opened ditches (Ahlers et al. 2016). The American mink is an invasive alien predator in Poland that mainly escapes from fur farms and endangers waterfowl and other birds, especially in areas distant from human settlements (Nordström et al. 2002; Brzeziński et al. 2012).

A similar phenomenon is the probable proliferation of beavers (Castor fiber) along small retention sites. The beaver's population, though previously almost extinct in Poland, has increased over the last 30 years to the extent that all possible sites-running water and channels-will be occupied by them. Beavers can increase overall forest biodiversity and water quality (Puttock et al. 2017). However, their growing population also has some negative consequences for forest management and planning.

\section{Hydrological Aspects and Monitoring the Efficiency of the Small Retention Programs}

The aim of small retention programs is to help in local drought and flood protection and lower the risk of wild fires. The small retention program was not clearly focused on flood management but rather aimed to establish a complex and ecologically sound water resource management in forests. In the lowland areas, small retentions decrease flood risk and mitigate droughts. In the mountain areas, water retention aims mainly at decreasing flood risks.

A forest is a natural storage reservoir and can be treated as a space for water retention. Water storage in forests can mitigate floods, as it flattens the flood wave. The type of trees, their age, height, compactness, undergrowth, litter, etc. have an impact on the success of the mitigation. Fresh, dry and mixed forests as well as moist mixed forests have the highest water storage capacity. They can store $28-30 \%$ of rainfall. Riparian and alder forests have much lower (10-13\% of rainfall) capacity (Mioduszewski and Pierzgalski 2009).

It is not fully determined how to measure of the efficiency of precautionary water retention measures in forests as it depends on many hydrological and geological factors and also on the scale of monitoring (Schüler 2006). Afforestation in a catchment is considered as an element contributing to water circulation. Poor permeable soils in the catchment area, with variations of land elevation, leads to a high degree of surface runoffs. The small retention reservoirs may further limit the flood wave and can therefore serve as an element of the flood risk reduction system beyond their purpose as land use planning measures. To perform the flood reduction function, 
small tanks must be equipped with valves enabling water retention only during the peak flow period (Mioduszewski and Pierzgalski 2009).

The quantitative assessment of small retention is usually not as evident (Miler 2015). A number of publications referring to the SWAT (Soil and Water Assessment Tool) models were developed to assess the impact of small retention measures on flood protection and mitigating the effects of drought. These models analyse elements of retention process, like the impact of wetland restoration on the flood wave or the impact of cultivation types on river flow. At the same time, the diversity of factors shaping the outflow process makes it impossible to draw universal conclusions about the impact of small water retention. Small retention processes are specific for a given catchment and climate, and scale of events (Mioduszewski and Okruszko 2016).

Concerning the small retention programs launched in Poland from 1997, a network of retention facilities covering the Polish forests has been planned to increase retention possibilities and counteract floods and droughts in forest ecosystems in lowland areas and the mountains (Mioduszewski and Pierzgalski 2009). Numerical modelling shows that the program is instrumental in providing water supply for plants and ecosystems during drought; however, they further prove empirically that the program's impact on flood protection is still a challenge (Mioduszewski and Okruszko 2016). Nevertheless, a number of studies have been published on monitoring the influences of retention in Polish forests. According to these studies, the smaller the pond and the smaller the value of the current water body retention, the bigger will be the relative increase of groundwater retention in the areas adjacent to a pond in relation to the increase of the water level in said pond (Juszczak et al. 2007).

An analysis of a small water retention resulting from installing weirs in the watercourse in small forest catchments of the Krajeńskie Lake District showed that the average value of the time constant for flood waves increased by about $50 \%$ following the construction of the reservoir (Miler 2015).

Small retention is limited in terms of achieving flood protection as a natural process is largely uncontrollable and difficult or impossible to regulate. A forest has a potential threshold retention capacity; thus the impact of a forest on flood flows is also limited to a certain amount of precipitation (Mioduszewski and Pierzgalski 2009).

\section{Synergies and Tensions Between Functions}

Tensions and collisions between the small retention program activities and biodiversity conservation, as mentioned above, are related to the fact that a large number of forests are part of the Natura 2000 network. In accordance with the Natura 2000 conservation principles, all investments need to be screened in terms of their environmental impact. As a result, construction of retention facilities requires permissions issued by the environmental protection administration and building permissions issued by the county administration and by the municipalities. 
In general, some small retention measures, such as building small retention reservoirs on rivers, reservoirs built in local terrain depressions and reconstruction of small ponds, can have negative impacts on ecosystems (destruction of valuable ecosystems, problems with fish migration, changes in ecosystems, changing ecosystems to less valuable ones, etc.). Moreover, there are collisions with agricultural production (loss of agricultural area; the possibility of excessive waterlogging of the soil etc.) (Mioduszewski and Okruszko 2016). An important collision relates to focus on retention versus focus on biodiversity protection. Planners of retention programs need to verify the location of investments in order to deal with this issue. Hydrologists engaged in the program look at a proposed measure's design thoroughly in terms of water flow and the retention targets to be achieved. Therefore, they search for a feasible and cost-effective solution and the best locations. However, the proposed locations are not necessarily valuable from the perspective of biodiversity conservation. For instance, from the point of view of flood management enlarging an existing pond can lead to a significant increase of retention potential, but it could mean enlarging an already wet area. From a biodiversity protection standpoint, installing a pond in an area scarce in terms of surface water would be more valuable.

Although the tensions between functions and sectors can cause difficulties for small retention, the implementation of the small retention programs in the forests faced relatively few problems of this type. This happy circumstance was due to two main reasons: firstly, most of the measures were applied in forests owned by the SF National Forest Holding. The dominance of one owner of land and one sector (forestry) diminishes the collisions. Secondly, the project was executed on a competitive basis. The SF National Forest Holding units or other interesting stakeholders proposed the measures and locations. It helped to eliminate proposals, a process that tends to elicit tensions. In this respect, the program is based on the no regret solutions strategy. Thirdly, stakeholders as environmental NGOs and experts were involved in the planning processes, for example in publishing a handbook on technical aspects of small retentions (CKPŚ 2009, 2008; Goździk et al. 2009; CKPŚ 2016) was consulted by seven NGOs. This is a good way to handle different points of view and conflicts in an attempt to achieve an all around win-win situation.

\section{The Problem of up-Scaling}

The small retention program in the Polish Forests, in its consecutive phases, resulted in realizing several thousand local, small-scale projects. However, from the management point of view, the program can be treated as a top-down initiative. The SF National Forest Holding is a large organization with 450 territorial units and 25,000 employees. It has a hierarchical structure with strict rules and procedures. Therefore, any new approach has to be approved by the Headquarter Directors. The program was developed at the ministerial level and was launched by the director of the SF National Forest Holding. In 1997, the director of the SF National Forest Holding approved a guiding document: Principles of planning and implementation of small 
retention in the State Forests, defining the concept of "small retention". In 2002, a new agreement was signed "on cooperation to increase the development of small water retention and the dissemination and implementation of pro-ecological methods of water retention", which was signed additionally by the directors of the National Fund for Environmental Protection and Water Management and the Agency for Restructuring and Modernization of Agriculture. Moreover, the small retention program relies on Regulation No. 11 of the director of the SF National Forest Holding (February $14,1995)$ on improving forest management on ecological grounds and several other documents and guidelines concerning forest management. According to the current instructions, namely the Forest Management Rules (2012), the possibility of increasing retention in forests by improving functionality, restoration or construction of new drainage devices is taken into account (Liberacki et al. 2016). These documents set up the regulatory framework for realization of the small retention programs.

From this point of view, the regulatory background allowing for small retention initiatives was set by the top decision makers. At the same time, the project relied largely on bottom-up initiatives. The SF National Forest Holding territorial units needed to prepare projects and apply within a grant-like procedure. The chance to obtain financing was an obvious incentive, encouraging the territorial units to propose applications. The program was a success, with many applications. The quasi voluntary recruitment appeared effective in initiating the program and achieving the critical mass. However, this format also resulted in certain spontaneous characteristics in terms of program development. For instance, at the beginning, many projects were focused on dams on lakes simply due to the feasibility of such projects, which allowed for a quick increase of retention potential. When these options were used up, other measures became more popular. In order to supervise program consistency and the program life cycle, in the third phase the additional monitoring component was established.

\section{Conclusions}

After 1997, several small-scale retention programs in forests were introduced in Poland, reversing the earlier practice of drainage. Flood prevention is a part of a wider portfolio of the programs' benefits (forestry, agriculture, biodiversity protection).

The relative feasibility of the small retention program in terms of property rights can be attributed to a specific characteristic of the SF National Forest Holding. It is a corporation but shares many features of an organization working for the public interest. Moreover, it is a hierarchical organization; thus the decision of the headquarters to launch the programs was effectively implemented. Also, the SF National Forest Holding owns large forest areas, a crucial factor for an undertaking as demanding for space as water retention development. Although in several cases cooperation with local governments was successful, in most cases the Holding relied on its own properties. Next, the Holding was able to initiate the programs and to carry them out because of its good economic standing. Although the programs were subsidized, the 
initial investment was required and the Holding was able to sustain it. Finally, the hierarchical structure of the Holding was instrumental to up-scaling. At the beginning, the programs were experimental and followed a learning-by-doing method. It was later expanded and corrected. It was possible, largely, due to stability of the policy of the SF National Forest Holding.

The life cycle of the project (three phases over the course of 20 years) offers several lessons: (a) establishing an encouraging legal and institutional environment is crucial for initiating a program such as the small retention programs; (b) providing financial subsidies is a prerequisite for success; (c) a procedure with calls of proposals and application from the local branches of the Holding resulted in a search for "low hanging fruits", which helped to reach the critical mass and gather experience.

Acknowledgements Open access of this chapter is funded by COST Action No. CA16209 Natural flood retention on private land, LAND4FLOOD (www.land4flood.eu), supported by COST (European Cooperation in Science and Technology).

\section{References}

Ahlers AA, Heske EJ, Schooley RL (2016) Prey distribution, potential landscape supplementation, and urbanization affect occupancy dynamics of American mink in streams. Landsc Ecol 31(7):1601-1613. https://doi.org/10.1007/s10980-016-0350-5

Baldwin RF (2005) Vernal pools: critical habitat. Front Ecol Environ 9:471-477

Baldwin RF, Calhoun AJK, de Maynadier PG (2006) The significance of hydroperiod and stand maturity for pool-breeding amphibians in forested landscapes. Can J Zool 84:1604-1615

Brzeziński M, Natorff $\mathrm{M}$ et al (2012) Numerical and behavioral responses of waterfowl to the invasive American mink: a conservation paradox. Biol Conserv 147:68-78

CKPŚ (2008) Podręcznik Wdrażania Projektu—Wytyczne do realizacji zadań i obiektów małej retencji na ternach nizinnych: Zwiększanie możliwości retencyjnych oraz przeciwdziałanie powodzi i suszy w ekosystemach leśnych na terenach nizinnych (Project management tutorial-guidelines for realising small retention project on the lowlands: increasing the retention potential and mitigating flood and drought in lowland forest ecosystems). CKPŚ, PGL Lasy Państwowe, Warszawa

CKPŚ (2009) Podręcznik Wdrażania Projektu-Wytyczne do realizacji zadań i obiektów małej retencjina ternach nizinnych: Zwiększanie możliwości retencyjnych oraz przeciwdziałanie powodzi i suszy w ekosystemach leśnych na terenach nizinnych (Project management tutorial-guidelines for realising small retention project in the mountains: increasing the retention potential and mitigating flood and drought in highland forest ecosystems). CKPŚ, PGL Lasy Państwowe, Warszawa

CKPŚ (2016) Podręcznik Wdrażania Projektu—Wytyczne do realizacji zadań i obiektów małej retencji i przeciwdziałania erozji wodnej: Kompleksowy projekt adaptacji lasów i leśnictwa do zmian klimatu — mała retencja oraz przeciwdziałanie erozji wodnej na terenach nizinnych i górskich (Project management tutorial—guidelines for realising small retention project and prevent erosion: a complex project on the adaptation of forests to climate change, increasing small retentions and prevent erosion in lowlands and highlands). CKPŚ, PGL Lasy Państwowe, Warszawa

Di Mauro D, Hunter ML Jr (2002) Reproduction of amphibians in natural and anthropogenic temporary pools in managed forests. For Sci 48:397-406 
Fournier MC, Larrue M et al (2016) Flood risk mitigation in Europe: how far away are we from the aspired forms of adaptive governance? Ecol Soc 21(4):49-59. https://doi.org/10.5751/ES-08991210449

Goździk M, Guzek K et al (2009) Podręcznik wdrażania projektu—Wytyczne do realizacji małej retencji w górach: Przeciwdziałanie skutkom odpływu wód opadowych na terenach górskich. Zwiększenie retencji i utrzymanie potoków oraz związanej z nimi infrastruktury w dobrym stanie (Project management tutorial-Guidelines for realisation of small retention program on the highland forested areas. Mitigation of the impact of precipitation flow on the highland areas. Increasing retention and management of running waters and related infrastructures). CKPŚ, PGL Lasy Państwowe, Warszawa

Hanowski J, Danz N, Lind J (2006) Response of breeding bird communities to forest harvest around seasonal ponds in northern forests, USA. For Ecol Manag 229:63-72. https://doi.org/10.1016/j. foreco.2006.03.011

JASPERS (2009) Wstępna ocena zbiorników realizowanych w ramach projektu: Przeciwdziałanie skutkom odpływu wód opadowych na terenach górskich. Zwiększenie retencji i utrzymanie potoków oraz związanej z nimi infrastruktury w dobrym stanie (Preliminary analysis of retention sites realised within the project: mitigation of the impact of precipitation flow on the highland areas. Increasing retention and management of running waters and related infrastructures). JASPERS, PGL Lasy Państwowe, Warszawa

Jelonek M, Engel J et al (2008) Wstępna ocena projektu: Przeciwdziałanie skutkom odpływu wód opadowych na terenach górskich. Zwiększenie retencji i utrzymanie potoków oraz związanej z nimi infrastruktury w dobrym stanie (Preliminary assessment of the project: mitigation of the impact of precipitation flow on the highland areas. Increasing retention and management of running waters and related infrastructures). CKPŚ, PGL Lasy Państwowe, Warszawa

Juszczak R, Kędziora A, Olejnik J (2007) Assessment of water retention capacity of small ponds in agricultural-forest catchment in Western Poland. Pol J Environ Stud 16(5):685-695

Koseoglu N, Moran D (2014) Review of current knowledge. Demystifying natural water retention measures (NWRM). Foundation of Water Research, Marlow, Bucks, pp 3-15

Kowalczak P (2002) Hierarchia potrzeb obszarowych małej retencji dla wojewodztwa zachodniopomorskiego (Hierarchy of the local demand for small retention in the Western Pomeranian Region). IMGW, Warszawa

Kowalewski Z (2008) Actions for small water retention undertaken in Poland. J Water Land Dev 12:155-167. https://doi.org/10.2478/v10025-009-0012-y

Kundzewicz ZW, Dobrowolski A et al (2012) Floods in Poland. In: Kundzewicz ZW (ed) Changes in flood risk in Europe. IAHS Press

Liberacki D, Korytowski M et al (2016) Efekty realizacji programu małej retencji w lasach na przykładzie dwóch nadleśnictw obszarów nizinnych (Effects of realisation the small retention program in forests, on the example of two lowland forestry). Rocznik Ochrona Środowiska 18:428-438. ISSN 1506-218X

Miler AT (2015) Mała Retencja Wodna w Polskich Lasach Nizinnych. Infrastruktura i Ekologia Terenów Wiejskich (Infrastruct Ecol Rural Areas) 4(1):979-992. http://dx.medra.org/10.14597/ infraeco.2015.4.1.078

Mioduszewski W (2014) Small (natural) water retention in rural areas. J Water Land Dev 20(1):19-29. https://doi.org/10.2478/jwld-2014-0005

Mioduszewski W, Okruszko T (eds) (2016) Naturalna, mała retencja wodna-Metoda łagodzenia skutków suszy, ograniczania ryzyka powodziowego i ochrona różnorodności biologicznej (Natural small water retention - a method for lowering the effects of droughts and risk of floods, and increasing biodiversity). Podstawy Metodyczne, Globalne Partnerstwo dla Wody. http://gwppl. org/data/uploads/dokumenty/naturalna_mala_retencja_mioduszewski_okruszko.pdf

Mioduszewski W, Pierzgalski E (eds) (2009) Zwiększenie możliwości retencyjnych oraz przeciwdziałanie powodzi i suszy w ekosystemach leśnych na terenach nizinnych (Increasing retention capacity and flood and drought prevention in lowland forest ecosystems). CKPŚ, PGL Lasy Państwowe, Warszawa, pp 1-73 
Nordström M, Högmander J et al (2002) Variable responses of waterfowl breeding populations to long-term removal of introduced American mink. Ecography 25:385-394. https://doi.org/10. 1034/j.1600-0587.2002.250401.x

Pierzgalski E, Wolicka M, Niemtur S (2017) The environmental aspects of water management in mountain forests-Polish experiences. EFI technical report 101. https://link.springer.com/ chapter/10.1007/978-3-319-57946-7_2

Puttock A, Graham HA et al (2017) Eurasian beaver activity increases water storage, attenuates flow and mitigates diffuse pollution from intensively-managed grasslands. Sci Total Environ 576:430-443

Schüler G (2006) Identification of flood-generating forest areas and forestry measures for water retention. For Snow Landsc Res 80(1):99-114

Tyszka J (2009) Estimation and economic valuation of the forest retention capacities. J Water Land Dev 13a:149-159

Wegner S (1999) A review of the scientific literature on riparian buffer width, extent and vegetation. Publication of Office of Public Service and Outreach, Institute of Ecology, University of Georgia, Athens, Georgia, pp 1-59

Whitaker DM, Montevecchi WA (1997) Breeding bird assemblages associated with riparian, interior forest, and nonriparian edge habitats in a balsam fir ecosystem. Can J For Res 27:1159-1167

Zając S (2004) Legal and financial instruments in Polish forest policy. In: Schmithüsen FJ, Trejbalová K, Vančura K (eds) Legal aspects of European forest sustainable development. Conference proceedings. https://doi.org/10.3929/ethz-a-005977041

Piotr Matczak studied sociology, culture science, and environmental management in Poland and the Netherlands. He is the Chair for Local and Regional Governance at the Institute of Sociology, Adam Mickiewicz University in Poznan (Poland). His research covers governance and institutional aspects of public policies concerning natural disasters, water management, climate change, and nature conservation.

Viktória Takács studied biology and environmental management in Hungary and in the Netherlands, obtained a Ph.D. in Poland. She participated in several projects concerning ecology, ecosystem services, forest biodiversity monitoring, and nature conservation.

Marek Goździk studied forestry and environmental engineering in Wroclaw (Poland). He holds a doctorate in river engineering. Currently, he coordinates small retention projects in State Forests (CKPŚ).

Open Access This chapter is licensed under the terms of the Creative Commons Attribution 4.0 International License (http://creativecommons.org/licenses/by/4.0/), which permits use, sharing, adaptation, distribution and reproduction in any medium or format, as long as you give appropriate credit to the original author(s) and the source, provide a link to the Creative Commons license and indicate if changes were made.

The images or other third party material in this chapter are included in the chapter's Creative Commons license, unless indicated otherwise in a credit line to the material. If material is not included in the chapter's Creative Commons license and your intended use is not permitted by statutory regulation or exceeds the permitted use, you will need to obtain permission directly from the copyright holder. 